\title{
The Influence of Environmental, Social, and Governance (ESG) Disclosure on Firm Financial Performance
}

\author{
Raisa Almeyda ${ }^{1}$, and Asep Darmansyah ${ }^{1}$
}

\begin{abstract}
The aim of this study is to do research about nonfinancial aspect that has influence toward the companies' financial performance, that will highlight the scores of companies' ESG (Environment, Social, Governance) disclosure. Nowadays, investors take into account the non-financial aspect into their investment decision, such as ESG performance as a risk measurement. The mixed of results found in the previous studies regarding the correlation between company ESG/CSR and financial performance warranted us to conduct more research in this particular topic. We conducted research on companies in the real estate sector since its long-term nature of investment is aligned with long-term ESG goals. The samples of companies were collected from seven countries with the strongest economy worldwide, the G7. The financial performance is measured by both in the perspectives of accounting and stock market, which are ROA, ROC, Stock Price, and P/E. The panel data was collected over five years (2014-2018), using STATA to run multivariate regressions to test for the correlations. The results indicate that there is a statistically significant positive relationship between the ESG disclosure with firm's $\mathrm{ROA}$ and ROC, but no significant relationship with Stock Price and P/E. Furthermore, we found that there is a statistically significant positive relationship between the Environmental factor towards the firm's ROC and Stock Price. Lastly, the study also reveals that there's no significant relationship between the Social factor and Governance factor with firm financial performance. The results show that a high transparency regarding ESG information could improve the financial performance. Thus, it is advisable for investors, company management, decision-makers, and industry regulators to consider the importance of the ESG disclosure.
\end{abstract}

Keywords-ESG, CSR, G7, Financial Risk Measurement.

\section{INTRODUCTION}

Environmental degradation is a quite serious problem along with the growth and development of companies in every country. One of the causes of environmental degradation is the use of resources carried out in ways that are not suitable for obtaining large economic benefits. In addition, the company's production activities can also produce environmental pollution which will have an impact on social conflict. Therefore, aside from improving their

${ }^{1}$ Raisa Almeyda and Asep Darmansyah are with School of Business and Management, Institut Teknologi Bandung, Indonesia. Email: raisa.almeyda@sbm-itb.ac.id; asep.darmansyah@sbm-itb.ac.id. governance aspect, firms might also have to consider their both their environmental and also social responsibilities so as to get the legitimacy for the social role and environmental concerns that have been carried out by the company, so that the company will gain trust and support from the community because rust and support obtained from the community might give a big impact on the sustainability of the firms in the future [1].

The environmental actions of the company relate to their efforts in building a good impact for the environment by following the regulations related to that particular aspect. The social actions is more about how they well they threat the stakeholders as well as the communities in which the firm is operating. The governance aspect is incorporating the firm's integrity and ethical behavior within the management system of the company including the board of directors.

The word ESG was introduced in 2005 where a study called "Who Cares Wins" initiated to search ways in incorporating the ESG aspects into the capital market. Moreover, the UNEP/Fi also created "Freshfield Report" that proved the relevance between the ESG issues and the financial valuation. Moreover, these studies also created the foundation of the Principles for Responsible Investment (PRI) launching in New York Stock Exchange. As an addition, the Sustainable Stock Exchange Initiative (SSEI) was also launched one year after that.

Recently, the financial markets around the world have been exposed with environmental, social and governance (ESG) factors as one of the tools for the investment decision-making process [2]. A firm's ESG activities are considered as crucial because both institutional and individual investors see that ESG serves opportunities and risks facing the firm, as there is a study done by [3], stated that investors now use nonfinancial data such as ESG factors to decide whether to invest in a firm.

Therefore, from the investment perspective, the responsible investing is defined as the ethical investment, Socially Responsible Investing (SRI), and also Corporate Social Performance (CSP). Aside from considering the financial performance, they also take into account the Corporate Social Responsibility (CSR) actions as it has been growing rapidly around the world. In the United States and Europe, the market size is accounted for up to $17.9 \%$ and $58.8 \%$ respectively. It has been said that such 
amount have a huge enough impact on the financial market as a whole [4]. Those socially responsible investors consider the ethical investments, and try to avoid the "sin" investments. These are the reasons why the ESG disclosure is considered as important and being recognized by many regulators, investors as well as other related stakeholders. On the other hand, [5] has found out that although many stock exchanges in the world have regulated the listed companies to disclose their CSR actions, most of them are still considered as voluntary.

Nowadays, many countries are creating their effort in improving their regulations and laws that incorporate the firm's compliance with GCG and Transparency \& Disclosure (T\&D) standards so that the firms are getting their governance and T\&D practices rated in order to give a sense of their quality regarding such issues and keep trying to do improvement. The corporate governance is now becoming an important evaluation in investment decisionmaking tool because many research findings proved a correlation between the corporate governance and financial valuations, stock price performance as well as financial ratios. Therefore, a lot of investors now take a look at the corporate governance element when they create investment decision. They might think a poor performance of corporate governance as a risk facing the firm itself. Therefore, it is important for the firms to improve their corporate governance qualities to attract the capital from investment [6].

For the guidelines of firm's CSR reports, there are numerous frameworks existed, such as the UN (Global Compact), Global Reporting Initiative (GRI), Integrated Reporting Council (IIRC), etc. These are the guidelines that cover the environmental, social, and governance aspects. But, these guidelines do not serve as a reliable measure that could be used as a comparison between firms in different or same industries. Furthermore, the complexity, content and style of the CSR information disclosed by the firms are different from one to another, it therefore created difficulties among the stakeholders to judge the ESG performance of these firms in order to understand which one might perform better from another [7].

Bloomberg ESG data gives detail reports regarding the board independence, employee turnover, as well as board composition, etc. These data are updated every year. The usage of the ESG ratings are similar with the common investment trends around the ESG integration practices and currently also being observed in the financial markets [8], [9], stated how it can also be a credible source of information that can give considerable advantages for the researchers in terms of saving cost as well as saving time. Bloomberg provided evaluation of the companies annually to obtain public ESG information done by the companies through their CSR reports, annual reports, websites, and even company direct contact. This data will be crosschecked and will be standardized according to their industry. They cover 120 ESG factors and would penalize the companies if there is any "missing data". Therefore, this study is collecting data from Bloomberg to obtain the ESG scores.

The real estate sector has been engaged with the Responsible Property Investment (RPI) and is gaining a lot of attention within the real estate investment world. It is defined as the integration of environmental, social, and governance (ESG) factors that is considered as investment decisions for the investors in real estate sector. The RPI principles are needed to understand about the environmental, and social issues like resource scarcity climate change, mass urbanization on macro property trends, and many other potential issues that might hazard the long-term performance of the property businesses and assets.

Despite the difference in names, the core value of these definitions is the bridge between business and the incorporation of non-business related values. Since most companies in the real estate sector are asset-managed based and thus have long-term nature of investment, it is aligned with long-term ESG and CSR goals. A good ESG actions give implications about the expected cash flow distribution, decreased costs of agents, and might as well reduce investors' risk premiums. Moreover, the cost of capital would also be reduced as these socially responsible investors might be ready to receive a lower return from a socially responsible firms. This is by meaning that the firms with good ESG commitment would be more stable and resilient in terms of their operations and financials.

Environmental, social and governance risk is not just an issue for developing market investments. In developed countries the stakeholders such as the shareholders, regulators, creditors, media, environmentalists pay more attention to the CSR information than those in developing countries [10]. Many different aspects that drive the CSR reports in developed and developing nations. Therefore, we need to understand these differences since there are many different elements of CSR in developing countries [11], it can be different because of the religious influences [12] as well as levels of their state of economy. Therefore, it has been questioned whether or not the CSR frameworks between nations are transferable. This study chooses nations included in the Group of Seven as the subject of the research in order to avoid the impact of the difference in the economy on the results. These countries are the seven largest economies in the world as described by the IMF. It accounts up to $58 \%$ of the global net wealth.

In international scope, there are many negotiations about environmental and social issues that cover areas such as (corruption, supply chain, diversity, human rights, etc). And it has been taken place within many different institutions. Some of them are from intergovernmental like the ILO, EU or European Union, UN or United Nations, the Council of Europe, Group of Seven, International Finance Corporation, and etc). In 2007, the Group of Eight 
which is now known as Group of Seven due to the suspension of Russia's membership, did a summit declaration which had the topic about promoting the opportunities offered by doing more actions regarding the prevention of climate change, in terms of innovating, development of technology and reducing the poverty.

These strong economies were together forming range of policies in terms of market-based mechanism, which includes tax incentives, emission-trade, regulatory measurement and also technology cooperation. Moreover, they also shared a long-term vision in guiding investment decisions in order to strengthen the energy security, promote sustainable development, then cut the global emissions of greenhouse gases significantly.

Moreover, during the summit declaration, they also mentioned to encourage the information and transparency from the companies in terms of their actions regarding Corporate Social Responsibility actions. A number of new standards and principles in this particular topic was issued. The also invited the listed firms in their Stock Exchange markets to pay more attention in assessing their Corporate Social Responsibility standards and principles compliance in the same way they do to their annual reports nu asking the OECD and cooperated with Global Compact as well as the ILO in order to assess the most suitable Corporate Social Responsibility standards so that it would give more holistic picture in the various guidelines and principles. In addition, they also declared that they emphasized the UN Global Compact as their Corporate Social Responsibility initiative. In 2018. The G7 did summit again in Canada to proclaim that they were committed to measuring their Corporate Social Responsibility and Sustainability Progress.

The growing idea of ESG investment can be proved by the rising of global investment in the Environmental, Social, and Governance related firms from seventeen trillion dollars to twenty-eight trillion dollars started from the 2012 until 2014 [13]. A study done by [14] proved a significant and positive relationship between Environmental, Social, and Governance (ESG) and firms valuations that indicated firms with higher ESG perform better in terms of their corporate financial performance. This gives a sense of the relevance for them to be considered as investment decision factors. Therefore, in order to be successful, corporations should not only be responsible to the holders of the shares, but also their stakeholders that take care in the social and financial of the firm [15]. A lot of other previous research that has been using different indicators of firm financial performance, such as a research done by [16], [17] who compared different corporate governance to their ROA, ROE and Tobin's Q. Results were varied, some found it to be positively correlated, negatively correlated, and even no correlation at all.

Many different methods could be used to analyze firm's financial performance. One of the most important one is when it comes to analyzing the financial data derived from firm's financial statement, which is the ratio analysis. It is crucial because pas performance is usually considered as an indicator of the future performance [18]. These ratios are in correlation among the figures in the financial statements. The ratio analysis is one of a techniques to examine the accounting statements which means that it could be used to create a trend over years as well as for comparing them among different firms in the same industry. Therefore, as a measure of accounting-based performance, we would be using ROA and ROC.

\section{Problem Identification}

After explaining the background, the growing market size of Socially Responsible Investing (SRI) along with how ESG disclosure has been becoming more recognized by more and more regulatory agencies, exchanges, and investors pique our interest in conducting a study in this particular field. As we have discussed earlier, most companies in the real estate sector have long-term nature of investment which is aligned with long-term ESG and CSR goals. The increasing concept of Responsible Property Investment (RPI) within the real estate investment that integrates the ESG aspects into investors' decisions also gives signal that there is a need to conduct research about this particular issue in this sector.

Moreover, in the developed nations, the stakeholders including the media, regulators, and society are more concerned about the firms CSR actions. For instance, the countries in G7 declared that they emphasized, that United Nations Global Compact is an important initiative. On the summit declaration, they also mentioned to improve the transparency of the companies in terms of disclosing their CSR related information to the public by issuing more policies and regulations.

Therefore, we are curious whether or not there is a correlation between the real estate company's ESG disclosure score in developed markets with their financial performance. This study will try to analyze the impact of ESG disclosure score to the financial performance such as ROA, ROC, Stock Price, and P/E as well as enlarging the subtopics on the current literature, by including the each component of Environmental, Social, and Governance disclosure variables as well as assessing them with a different set of data because by including the three individual factors of ESG disclosure score, it would give us the chance to assess how each ESG factor could give considerable impact to the financial performance improvement and which of these three ESG scores is the key driver for improving financial performance.

This large data set will be derived from 77 listed real estate companies with the total of 380 observations. The G7 is being chosen in order to avoid the influence of the economic difference on the results as well as due to some reasons that have been mentioned earlier on the background of this study. 
Against this background, the aim of this study was to:

1. To examine whether the ESG disclosure score has significant influence toward the firm's financial performance.

2. To examine whether the Environmental factor of ESG disclosure score has significant influence toward the firm's financial performance.

3. To examine whether the Social factor of ESG disclosure score has significant influence toward the firm's financial performance.

4. To examine whether the Governance factor of ESG disclosure score has significant influence toward the firm's financial performance.

The rest of the paper will be built from the review of relevant literature on the subject addressed, the details on the research methods used for this study, the results and discussions, and the last part will be consisted of the summary, conclusion and recommendations based on findings.

\section{LITERATURE REVIEW}

\section{A. Environmental, Social, and Governance (ESG)}

Environmental, Social and Governance or ESG in short, is a common term used in Corporate Social Responsibility (CSR) of a company. Recently, ESG information has now becoming everybody's concerns due to the potential longterm impact given to the investment of the stakeholders rather than limited only to the shareholders. There are numerous names given to ESG, but not limited to Corporate Social Disclosure (CSD), Corporate Social Responsibility Disclosure (CSRD), etc [19].

It is the practice to measure, disclose as well as to become accountable to all the stakeholders both within and outside of the companies. ESG score of a company reports the performance of them towards the goal of sustainable development. The ESG report covers the firm's usage of sources, natural resources, human rights, and their level of corruption, how they invest in community relations, etc. The shareholders often see the ESG report as it is linked to the firm's strength, risk management, as well as their effectiveness [20].

1) Environmental

Climate change is a topic that has been around in the early $21^{\text {st }}$ century, as it is one of the urgent prominent issues for all the human race. Which is why this issue has particular relevance for companies in regard to its financial markets [21]. In the near future, firms will most likely have to operate under harsher environments. For instance, changes in regulations on various industry in respond to activist demand in stopping climate changes will have a direct impact on how business operates [22].

Environmental disclosure results of corporate are generally obtained from the analysis of the firm's publicly available information including their annual reports, their reports regarding environmental actions, websites etc [23].
It covers all the environmental factors including the reduction in emission, the resources' consumption and other innovations related to increasing the protection of the environment [24].

\section{2) Social}

Social score is a score that measures issues that deal with consumers and how they respond to the products, also other societal issues like donations, the ethics in conducting business activities and how their effort in respecting the human rights [24]. The social performance is a crucial indicator of how the company performs including their performance within the ESG framework [25]. There has been a trend of putting the focus on Corporate Social Responsibility which is more concerning about the social aspects [22]. Furthermore, this dimension includes some aspects concerning the labor force, with regard to their health and safety as well as diversity of human resources. The relevance of this specific indicator is also laid within the Socially Responsible Investment (SRI) strategies as it tries to evaluate the concept of firm's long-term performance as it relates to their risk evaluation [26].

\section{3) Governance}

Governance in the ESG framework could be described as a set of process, structure and system that are integrated for the company to be able to grow successfully [27]. The corporate governance is more about how the firms are managed and controlled by the managerial roles [28]. Therefore, it is a vital factor that is useful in terms of improving the efficiency of the economic development issues along with the needs to enhance the trusts of the shareholders. Moreover, the governance also takes into account the relationship among the board of directors, shareholders, managerial roles, as well as other related stakeholders within the firms or organizations [25].

This particular aspect has been gaining a lot of attention lately due to the separation of ownership control and managerial roles in the business activities within the firms. Oftentimes, the managers' interest clashed with the shareholders' interest. This is why the issue about principal-agent occurred when the management direction is different with the stakeholders' interest. We can conclude that actually the definition of the corporate governance itself is still unclear due to many perspectives of describing it. Berle, et al., 1932 has been describing the governance as the structure of the capital, the incentive of the managerial roles, the ownership distribution, the competition of the products in the market, and even the structure of the organization itself.

\section{B. ESG Disclosure}

The economic markets globally have been moving towards the models of investing strategy that incorporate the ESG dimensions [29]. The ESG disclosure score is able to quantify the company's voluntary disclosure in terms of their environmental, social, and governance (ESG) information. It is considered as a significant variable due 
to its ability to enable a business showing their management performance, thus able to identify risks relating to their ESG performance [30].

One of the issues that we currently face is how to assess the quality of the ESG reports as many global organizations including United Nations Conference on Trade and Development (UNCTAD), Global Reporting Initiative (GRI), European Federation of Financial Analysts Societies (EFFAS), etc are trying their utmost to develop the performance indicators for assessing the ESG report. Many other organizations like G20, the EU, and other nations such as France, Germany, UK, Japan, etc are trying to initiate the integrated reporting of ESG data. These factors generated the issues of firms could cherry-pick the indicators that might give them advantage outcomes [31].

Therefore, a distinctive set of key performance indicators for ESG is essential to support investor choices. The data derived from the ESG could help the investors to have broader information that can be taken into account when considering an investment. Therefore, they could take a look at businesses that might reveal more ESG information as they are more ready to be analyzed.

\section{CSR Reporting Regulation in G7 Countries}

As explained in the previous chapter, this paper is concerned with the seven economic power of the world, the members of the G7 group, namely the France, Germany, Italy, Canada, United States, United Kingdom and Japan. It has been said that the most crucial and robust drivers of worldwide CSR reporting regulation are a country's GDP level and international organizations' attempts to promote it [32]. The author also indicated that one of the variables stimulating the development of CSR regulation is the growing expectation of stakeholders and civil society about the behaviors of governments to regulate companies. The company's primary stakeholders include customers, investors, community, employees, company partners, governments, and the public, particularly for large companies with important environmental and social effects.

[33] has stated that from all 850 leaders' opinions coming from the United States, United Kingdom, France and Germany, around half of them agree with the declaration that these nations want to be stricter in creating regulations for the private businesses operating in their countries. And with the economic and social development, stakeholders and the effects of civil society are becoming more important as they are getting more channels to voice their complaints and request, which therefore created the needs for the government to initiate an action in regulating the CSR.

In 2010, the US Securities and Exchange Commission or also known as the SEC published Interpretive Guidance on Climate Change Disclosure. This offers guidance on disclosure regulations that may require a company to reveal the effect on its business that climate change-related legal developments may have impacted. In the EU, under
Directive 2014/95/EU, big firms (more than 500 workers) are required to publish reports on their policies regarding environmental protection, social responsibility and employee treatment, respect for human rights, anticorruption and bribery, diversity on members of the business board. Public companies must reveal all material data under Canadian securities laws, including material data on environmental and social issues, as well as extra disclosure responsibilities under the timely disclosure strategies of TSX and TSX Venture Exchange [34].

Therefore, we can conclude that the organizational climate promotes businesses to reveal data, albeit restricted information, on environmental, social and governance problems. Because institutional pressures are seen as a significant reporting driver.

\section{ESG Measurement}

In 1996, reports on corporate social responsibility (CSR) were produced by only 300 companies globally. 19 years later in 2014 , this number had increased to more than 7,000 participating companies around the globe [35]. While the Global Reporting Initiative (GRI) guidelines and more recently the framework recommended by the International Integrated Reporting Council have been adopted by many companies, the extent and quality of ESG disclosure remains heterogeneous.

The database of ESG has several benefits over other databases that are openly accessible. The ESG database is adopting the most extensive methodology for calculating and assessing the environmental, social and governance operations and performance of businesses [36]. It evidently separates processes and results of governance related to CSR. Bloomberg's ESG group initially created the ESG database in early 2008.

Bloomberg's product offers over 9,000 businesses in over 70 nations with insight into ESG metrics. Their product involves derived ratios and sector-specific areas. It offers up to 10 years of historical information in addition to comprehensive coverage. 900+ areas are included ESG Disclosure Scores and span across several sustainability key topics.

The database of Bloomberg ESG offers comprehensive ratings ranging from 0 to 100 for each of the classifications of environment, social and governance. The Bloomberg Sustainalytics says that the ESG disclosure could help investors with a macro-level assessment of how the firms manage their ESG capita. This allows investors to add the ESG indicators into their basic valuation. Thus, adequate data is provided by the ESG database to examine the interactions between CSR operations, CSR performance and financial performance.

\section{E. Financial Performance Measurement}

Financial performance can be described as a description of the financial circumstances of a given period for fundraising and fund allocation elements, which are 
generally measured by capital adequacy, liquidity and profitability indices [37]. Accounting performance and market performance measurements are generally used to evaluate firms ' financial performance. Measures for accounting results include return on asset, return on investment, profit margins and etc. While market performance includes market value to book value, stock performance and etc [38].

A restriction of financial measures is that they reflect stock market investor expectations that could alter rapidly due to uncontrollable occurrences managed by the firm (e.g. economic changes due to international crisis or investor perceptions of interest and inflation rates due mainly to domestic fiscal policy). Although accounting and market-based measures supposedly evaluate overall firm performance, they provide different evaluations of a firm's performance due to the timing (past or present) and the nature (retrospective or prospective) of these different measures [39].

\section{F. Financial Performance and ESG}

The issue of how ESG variables impact the economic performance of a company and, eventually, its value was the topic of contentious discussion. The early knowledge was based on neoclassical theory that the connection between ESG and economic results was consistently negative [40]. But, in particular, decision-makers should take into account company ethics and social accountability, and specifically environmental management. In reality, the concept of corporate social responsibility is being given rising attention by enterprises and communities [41].

Because of the connection between financial performance and investment in environmental concerns, companies are generally double-minded about investing in environmental problems. Some companies believe that environmental programs by cost savings provide a competitive advantage (using less energy, recycling of wastes etc.) and by achieving higher customer satisfaction, staff loyalty and acquiring a favorable reputation as well as compliance with regulations. On the other side, if the company invests in bad environmental attempts, due to inefficiency and unnecessary investment, economic performance will be negatively impacted [42].

\section{G. Previous Research / Prior Studies}

Empirical literature used qualitative and quantitative techniques to examine the connection between CSR performance and economic performance. Some empirical studies were case studies using a qualitative approach to the implementation of environmental management. These studies evaluated specific companies and lacked generalizations of statistics [43]. The literature disclosed mixed outcomes for the correlation between performance of CSR / ESG and financial performance, demonstrating that the region could be further investigated. The diverse findings reported by these past research could be explained by many possible factors, including the variable information sources for CSR outcomes and the consideration of moderation and mediation factors [44].

\section{Methodology}

\section{A. Research Design}

The following are the steps for conducting the research:

1. Finding problem identification

2. Defining research objectives

3. Reviewing the literature

4. Defining the methodology to collect data

5. Analyzing data and presenting results/findings

6. Concluding result as well as giving recommendation

\section{B. Data Collection}

The data that was used in this study derived from the Bloomberg Terminal in year on year basis in order for us to be able to get the quantitative data and transform them into a panel data format. The other necessary data were taken from secondary data such as websites, reports, journals, etc. The Bloomberg Terminal was used to gather the ESG data due to small number of previous studies using it. Most of the previous researchers have been using Asset4, FTSE4Good, Goldman, Dow Jones Sustainability Index, manually transform qualitative data into quantitative by using GRI frameworks, etc.

\section{Data Analysis}

In order to be able to evaluate the influence between environmental, social and governance disclosure on financial indicators, multi regression will be performed based on panel data analysis. Panel data is defined as data set constructed from cross sectional and over time data. Regressions will be run to evaluate the correlation between the dependent and independent variables by considering the time dimension of the variables [45]. The independent variable of this research is the ESG disclosure score based on Bloomberg ESG data index. And the dependent variables are ROA, ROC, Stock Price and P/E. The ESG scores of the companies are measured for five years period from 2014 to 2018 as well as the financial performance data.

The sample was selected from listed real estate companies in the G7 countries (Canada, France, Germany, Italy, Japan, United Kingdom, and the United States), with a total observation of 380 .

For instance, if we would like to evaluate the influence of ESG disclosure on stock price of G7 listed real estate companies, the basic equation would be as follows:

$$
\mathrm{FPi}, \mathrm{t}=\beta 0+\beta 1 \text { ESGi, } \mathrm{t}+\beta \text { Controli, } \mathrm{t}+\varepsilon \mathrm{i}, \mathrm{t}
$$

Where :

FPi,t is for the financial performance of the company $i$ on the last year of the year $t$.

ESGi,t is a measure of ESG disclosure score of the company i 
Controli,t is the control variable $\varepsilon i$ the error term

TABLE 1.

MODEL DESCRIPTION

\begin{tabular}{|c|c|c|}
\hline Model & $\begin{array}{l}\text { Dependent } \\
\text { Variable }\end{array}$ & $\begin{array}{l}\text { Independent } \\
\text { Variable }\end{array}$ \\
\hline Model 1 & ROA & ESG Score \\
\hline Model 2 & ROA & $\begin{array}{ll}\text { Environmental Score, } & \text { Score } \\
\text { Social Score and } \\
\text { Governance Score }\end{array}$ \\
\hline Model 3 & ROC & ESG Score \\
\hline Model 4 & ROC & $\begin{array}{ll}\text { Environmental Score, } & \text { Score } \\
\text { Social Score and } \\
\text { Governance Score }\end{array}$ \\
\hline Model 5 & Stock Price & ESG Score \\
\hline Model 6 & Stock Price & $\begin{array}{lr}\text { Environmental Score, } \\
\text { Social Score and } \\
\text { Governance Score }\end{array}$ \\
\hline Model 7 & $\mathrm{P} / \mathrm{E}$ & ESG Score \\
\hline Model 8 & $\mathrm{P} / \mathrm{E}$ & $\begin{array}{l}\text { Environmental Score, } \\
\text { Social Score and } \\
\text { Governance Score }\end{array}$ \\
\hline
\end{tabular}

\section{Variables}

1) Dependent and Independent Variables

The definitions of the dependent and independent variables and their expected signs are as given on the table below.

TABLE 2.

\begin{tabular}{|l|l|l|}
\hline \multicolumn{2}{|c|}{ DEPENDENT AND INDEPENDENT VARIABLES } \\
\hline ROA & $\begin{array}{l}\text { Types } \\
\text { Dependent }\end{array}$ & Refinition \\
\hline ROC & Dependent & $\begin{array}{l}\text { Return } \\
\text { Capital }\end{array}$ \\
\hline Stock Price & Dependent & $\begin{array}{l}\text { Stock price in the } \\
\text { end of period }\end{array}$ \\
\hline P/E & Dependent & $\begin{array}{l}\text { Price-to- } \\
\text { Earnings ratio }\end{array}$ \\
\hline Environmental & Independent & $\begin{array}{l}\text { Firm } \\
\text { Environmental } \\
\text { disclosure level }\end{array}$ \\
\hline Social & Independent & $\begin{array}{l}\text { Firm } \\
\text { disclosure level }\end{array}$ \\
\hline Governance & Independent & $\begin{array}{l}\text { Firm governance } \\
\text { disclosure level }\end{array}$ \\
\hline ESG & Independent & $\begin{array}{l}\text { Bloomberg ESG } \\
\text { data index }\end{array}$ \\
\hline
\end{tabular}

\section{2) Control Variable}

Control Variables are also used in this research. Using control for the effect of that the size of the company and leverage may have correlation between share price and CSR disclosure in robustness test [46]. This research use Total Asset of every company as well as their Market Capitalization as control variable. As an addition, we will also use Country variable to represent the country effect and will not use the economic variable like GDP for every country since our subjects are countries with the seven economic power of the world thus have removed the influence of difference in the state of the economy on the results. Moreover, since this is a panel data, we also use year effect as dummy variable.

\section{E. Classical Linear Assumption Test}

Before running the regression, Classical Linear Assumption Test is needed. With this assumption of the classical linear regression model (CLRM), we were able to fulfill several statistical things such as unbiasedness, minimum variance, etc [47]. For panel data, the analysis will be conducting the multicollinearity test, heteroscedasticity test, and normality test to reduce potential biases which may appear in regression model and to confirm the validity of data that will be used in regression.

\section{1) Multicollinearity Test}

The multicollinearity test is used to validate whether there is any linear correlation between an independent variable with the other independent variables [48]. Assumption 10 of the Classical Linear Regression Model (CLRM) is that there should be no multicollinearity problems between regressors. For more reason in time series data, there is a common trend in the regressors. The hypothesis of multicollinearity test is:

H0: There is multicollinearity

$\mathrm{H} 1$ : There is no multicollinearity

When the coefficient between variables $>0.8$, accept $\mathrm{H} 0$ or there is multicollinearity. On the contrary, if coefficient $<0.8$ reject $\mathrm{H} 0$.

The VIF test could help us reveal whether or not there are multicollinearity issues in the specified model. The VIF indicates how strong is the linear dependencies and how much the variances of every regression coefficient is inflated because of the collinearity comparing when the independent variables are not linearly related. The VIF for the predictor variable $\mathrm{X} k$ is given by $1 /(1-\mathrm{R} 2 \mathrm{k})$. Therefore, this test could be conducted to test for the multicollinearity issues among the independent variables. And if the result of the VIF is below or equal to ten, that means it shows no multicollinearity. While a value of VIF above 10 indicates multicollinearity issues.

2) Heteroscedasticity Test

An assumption of the classical linear regression model is that the disturbance appeared in the regression function should be homoscedastic which means that all of them have the same variance. We could conduct the BreuschPagan / Cook-Weisberg test in order to detect the heteroscedasticity. H0: Constant variance, means the robust standard error is relatively consistent with standard error. If prob>chi2 is less than significant level, it is indicating presences of heteroscedasticity. However, if heteroscedasticity presents in our model, by default Stata statistical software assumes homoscedastic standard errors if we adjust our model to account for heteroskedasticity. To do this, we can use the option robust in the regress command. 


\section{3) Normality Test}

The normality test is used to determine whether the data used are normal or not based on the available distribution [49]. Normality test could be conducted using several methods. We use Shapiro-Wilk W test for normality for each variable. If the prob $>\mathrm{z}$ is higher than significant level, it means the data is normal. However, in the practice of normality, it would not be a problem if we have such a big sample size. Because if the sample is greater than 30 , the central limit theory would be applied. This theory says that the methods would be the same as if the population itself were distributed normally when it comes to evaluating probabilities related with the values of statistical tests [49].

\section{F. Regression Analysis}

If we have passed the classical linear assumption tests, we will start conducting the regression models in order to find the correlation between variables mentioned earlier. We choose to use panel data by combining time series of cross-section observations. The output of this regression is coefficient determination, F-test, and T-test. The use of the panel data format would provide us a more useful result with less collinearity between the many different variables, panel data is usually defined as a more appropriate and efficient for multidimensional analysis due to its ability in identifying some correlations that might not be noticeable in a time-series data set or simple cross-section [50].

Regression method in panel data have three models, such as:

- OLS Regression

This regression model is considered as the simplest approach that ignore the time as well as the space element of the pooled data.

- $\quad$ Fixed Effect

Fixed effect is the way to consider the individuality of every company or every cross sectional unit to let the intercept vary for each company however it still assumes that the slope coefficient is constant across firm.

- Random Effect

Using of random effect is if we include the error term in the intercept of time series and cross-section data to make more efficient approach.

Several test is needed before we decide what approach we need. Breusch-Pagan Lagrange Multiplier or LM test to help us in deciding whether to run a random effects regression and a simple OLS regression. If Prob > Chi2 less than the significance level, we can use random effects regression. Hausman test helps us to decide whether to use fixed or random effects where the null hypothesis is that preferred model is random effect of fixed effect.

\section{G. Significance Level}

The significance level we choose would reflect our accuracy level, usually the standard is below $5 \%$, but it would be better at the $1 \%$ significance level. Because by using 5\% significance level, it means our model has a 95\% of confidence interval. Econometricians usually advise to use $1 \%$ instead for larger samples [51]. These are the factors why this study will use both $5 \%$ and $1 \%$ due to our large sample size.

\section{RESULT AND DISCUSSION}

\section{A. Data Presentation}

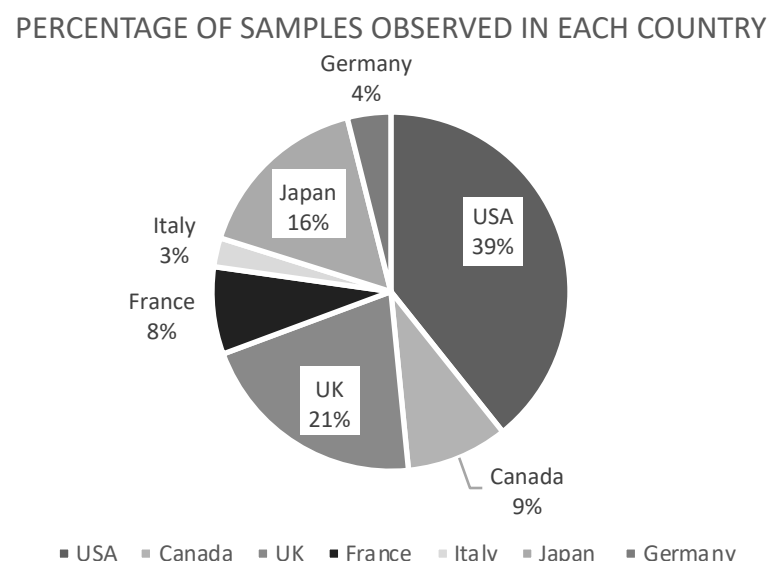

Figure 1. Percentage of Samples Observed in Each Country

The proportion of the data observed (listed real estate companies period 2014-2018) from every country can be seen in Figure 1. USA has the highest population for listed real estate companies, therefore, the samples derived from USA was the highest among other countries in G7, which accounts for 39\% of the observations. Followed by UK, Japan, Canada, France, Germany and Italy respectively.

\section{B. Descriptive Statistics Analysis}

TABLE 3.

DESCRIPTIVE STATISTICS

\begin{tabular}{|c|r|r|r|r|r|}
\hline Variable & Obs & \multicolumn{1}{c|}{ Mean } & \multicolumn{1}{c|}{ Std. Dev. } & \multicolumn{1}{c|}{ Min } & \multicolumn{1}{c|}{ Max } \\
\hline ESG & 382 & 33.07 & 12.34 & 11.16 & 59.09 \\
\hline Env & 382 & 25.04 & 15.61 & 1.55 & 65.89 \\
\hline Soc & 382 & 30.32 & 16.51 & 3.51 & 82.46 \\
\hline Gov & 382 & 54.87 & 7.94 & 14.29 & 75.00 \\
\hline ROA & 382 & 4.55 & 4.38 & -13.19 & 27.22 \\
\hline ROC & 382 & 5.63 & 5.22 & -13.79 & 30.17 \\
\hline $\begin{array}{c}\text { Stock } \\
\text { Price }\end{array}$ & 382 & 76.41 & 407.16 & 0.57 & 6258.49 \\
\hline PE & 380 & 42.32 & 74.74 & 3.65 & 905.46 \\
\hline Total_Asset & 382 & $1.09 \mathrm{e}+10$ & $1.02 \mathrm{e}+10$ & -9875497 & $5.70 \mathrm{e}+10$ \\
\hline Marketcap & 382 & $8.51 \mathrm{e}+09$ & $9.53 \mathrm{e}+09$ & $-2.74 \mathrm{e}+09$ & $6.02 \mathrm{e}+10$ \\
\hline Country & 382 & 2.90 & 1.98 & 1.00 & 7.00 \\
\hline
\end{tabular}

Table 3 shows the descriptive statistics of the variables. It depicts the number of observations sample of each variables $(\mathrm{N})$, mean, standard deviation, minimum, maximum of the variables used. The mean value of the 
overall ESG score of the listed companies is 33.07 with a standard deviation of 12.34. This means that the ESG score is spread out over a wide range of value from the time of observation. Meanwhile, the specific factors of ESG which are environmental, social, and governance have a varying mean between each of them. Environmental with only 25.04 score, followed by Social with 30.32, and Governance with the largest mean score of 54.87. With a low score and high standard deviation, means that the Social and Governance factor of the listed companies have a wide range of scores. While the Governance factor is quoted to have a considerably low score when comparing the standard deviation to its mean.

\section{Classical Linear Assumption Test \\ 1) Multicollinearity Test}

TABLE 4.

PAIR-Wise CORRELATION MATRIX

\begin{tabular}{|c|r|r|r|r|r|r|r|}
\hline Variable & \multicolumn{1}{c|}{ ESG } & \multicolumn{1}{c|}{ Env } & \multicolumn{1}{c|}{ Soc } & Gov & Total_Asset & Marketcap & Country \\
\hline ESG & 1 & & & & & & \\
\hline Env & 0.9425 & 1 & & & & & \\
\hline Soc & 0.8371 & 0.6599 & 1 & & & & \\
\hline Gov & 0.5822 & 0.4292 & 0.4452 & 1 & & & \\
\hline Total_Asset & 0.2425 & 0.2649 & 0.1096 & 0.1458 & & & \\
\hline Marketcap & 0.1115 & 0.127 & -0.0429 & 0.2154 & 0.6833 & & \\
\hline Country & 0.2212 & 0.2569 & 0.3117 & -0.3843 & 0.0523 & -0.3021 & 1 \\
\hline
\end{tabular}

Refer to Table 4, the Pair-Wise correlation shows that there is multicollinearity problem in Environmental and Social variables if we correlate it with ESG. However, this problem cannot be considered as a problem when the VIF test shows the VIF result <10 [52].

After doing the VIF test, we can see the results as seen on Table 5, indicate that multicollinearity problems in the specified model are unlikely existed, as the highest mean VIF value is 2.25 , followed by the least value of 1.76 . The value of VIF is beyond 10 means the multicollinearity is considered problematic. The number from Table 5 is well within the limit of 10 , so we can assume that there are no problems that arise from the test result.

TABLE 5.
VIF TEST
\begin{tabular}{|c|c|}
\hline Model & Mean VIF \\
\hline Model 1 & 1.77 \\
\hline Model 2 & 2.22 \\
\hline Model 3 & 1.77 \\
\hline Model 4 & 2.23 \\
\hline Model 5 & 1.76 \\
\hline Model 6 & 2.25 \\
\hline Model 7 & 1.76 \\
\hline Model 8 & 2.25 \\
\hline
\end{tabular}

\section{2) Heteroscedasticity Test}

Heteroscedasticity test aims to see whether the data is homogeneous or not, in other words, the data do not have any heteroscedasticity problems. We conduct BreuschPagan/Cook-Weisberg test in order to detect such problems. Table 6 summarizes the results.

TABLE 6.

Heteroscedasticity Test RESUlT

\begin{tabular}{|c|c|c|}
\hline Model & Chi2(1) & Prob > Chi2 \\
\hline Model 1 & 0.19 & 0.6642 \\
\hline Model 2 & 0.30 & 0.5843 \\
\hline Model 3 & 0.23 & 0.6290 \\
\hline Model 4 & 0.36 & 0.5486 \\
\hline Model 5 & 13.63 & 0.0002 \\
\hline Model 6 & 6.53 & 0.0106 \\
\hline Model 7 & 4.01 & 0.0451 \\
\hline Model 8 & 3.36 & 0.0670 \\
\hline
\end{tabular}

If prob>chi2 is less than significant level, it is indicating presences of heteroscedasticity. The result shows that model 5, model 6 and model 7 have some heteroscedasticity problems. However, if heteroscedasticity presents in our model, by default Stata statistical software would assume homoscedastic standard errors if we adjust our model to account for heteroskedasticity. To do this, we can use the option robust in the regress command.

\section{Normality Test}

Refer to Table 7 , it is shown that the residual value of this research is not distributed normally. This research has a total of 380 observations. Therefore, when the sample size is large, the central limit theory applies. This theory states that the methods would be similar, as if the population itself were normally distributed, when evaluating probabilities related with the values of a test statistic. When the sample size is large enough (greater than 30), the central limit theory applies and normality is assumed [49].

TABLE 7.

NORMALITY TEST

\begin{tabular}{|c|c|c|c|c|c|}
\hline Variable & Obs & W & $\mathrm{V}$ & $\mathrm{z}$ & Prob $>\mathrm{z}$ \\
\hline ESG & 382 & 0.95343 & 12.304 & 5.959 & 0.0000 \\
\hline Env & 382 & 0.95032 & 13.124 & 6.113 & 0.0000 \\
\hline Soc & 382 & 0.97891 & 5.571 & 4.078 & 0.0002 \\
\hline Gov & 382 & 0.95447 & 12.029 & 5.906 & 0.0000 \\
\hline Total_Asset & 382 & 0.80632 & 51.169 & 9.343 & 0.0000 \\
\hline Market_Cap & 382 & 0.75813 & 63.898 & 9.871 & 0.0000 \\
\hline Country & 382 & 0.95916 & 10.789 & 5.648 & 0.0000 \\
\hline Ln_ROA & 362 & 0.98437 & 3.936 & 3.245 & 0.0059 \\
\hline Ln_ROC & 363 & 0.97634 & 5.973 & 4.234 & 0.0001 \\
\hline Ln_SP & 382 & 0.97632 & 6.256 & 4.354 & 0.0001 \\
\hline Ln_PE & 380 & 0.97919 & 5.473 & 4.035 & 0.0003 \\
\hline
\end{tabular}


The $1^{\text {st }}$ International Conference on Business and Management of Technology (IConBMT)

August 3rd 2019, Institut Teknologi Sepuluh Nopember, Surabaya, Indonesia

\section{E. Regression Analysis}

1) Breusch-Pagan Lagrange Multiplier (LM) Test

Before running the regression, conducting the LM test helps us decide between a random effects regression and a simple OLS regression. The null hypothesis in the LM test is that variances across entities is zero. This is, no significant difference across units (i.e. no panel effect). If the prob>chibar2 is >significant level, then we can use OLS regression.

TABLE 8.

Breusch-Pagan Lagrange MultiPlier (LM) Test

\begin{tabular}{|c|c|c|}
\hline Model & chibar2(01) & Prob>chibar2 \\
\hline Model 1 & 84.00 & 0.0000 \\
\hline Model 2 & 82.77 & 0.0000 \\
\hline Model 3 & 62.04 & 0.0000 \\
\hline Model 4 & 63.56 & 0.0000 \\
\hline Model 5 & 361.02 & 0.0000 \\
\hline Model 6 & 368.01 & 0.0000 \\
\hline Model 7 & 204.86 & 0.0000 \\
\hline Model 8 & 200.04 & 0.0000 \\
\hline
\end{tabular}

After doing the LM test for all models, the results have shown that all models are appropriate for using random effects regression.

\section{2) Hausman Test}

In order for us to choose whether to use random effects or fixed effects, running a Hausman test is needed. If the Prob>chi2 is $<0.05$ (i.e. significant) use fixed effects.

TABLE 9.

Hausman Test Result

\begin{tabular}{|c|c|}
\hline Model & Prob>chi2 \\
\hline Model 1 & 0.9590 \\
\hline Model 2 & 0.4872 \\
\hline Model 3 & 0.9657 \\
\hline Model 4 & 0.3001 \\
\hline Model 5 & 0.0000 \\
\hline Model 6 & 0.0142 \\
\hline Model 7 & 0.0458 \\
\hline Model 8 & 0.2283 \\
\hline
\end{tabular}

Based on the result, only model 5, 6, and 7 have value of Prob>chi2 below the significant level. Therefore, it indicates that the random effect model is not appropriate and the fixed effect specification is preferred for the three models.

\section{3) Regression Result}

In order to test whether there is influence of ESG disclosure on the Financial Performance, we run the regression analysis. There are eight regression models which are consisted of four dependent variables. Every dependent variable is consisted of two regression models. One regression estimation includes four independent variables (ESG, Total Asset, Market Capitalization, and Country). The other regression estimation includes six independent variables (Environmental, Social, Governance, Total Asset, Market Capitalization and Country).

The Table 10 presents the result of regression of G7 listed Real Estate companies' ROA and ROC on ESG disclosure score while Table 11 presents the result of regression of G7 listed Real Estate companies' Stock Price and P/E on ESG disclosure score. Since the objective of this study is limited to only analyzing whether or not there is any significant influence between the ESG disclosure and the firm performance, the analysis part and the discussion part will not discuss the coefficient of every variable. However, the author still presents the information regarding the coefficients in the regression results tables.

TABLE 10.

REGRESSION RESULT MODEL 1-4

\begin{tabular}{|c|c|c|c|c|}
\hline Models & 1 & 2 & 3 & 4 \\
\hline \multirow{2}{*}{ Variable } & ROA & ROA & ROC & ROC \\
\hline & Coefficient & Coefficient & Coefficient & Coefficient \\
\hline ESG & \multirow[t]{4}{*}{$0.0113893^{* *}$} & & \multirow[t]{4}{*}{$0.0135145^{* * *}$} & \\
\hline Env & & 0.0059538 & & $0.0094025^{* *}$ \\
\hline Soc & & -0.0011669 & & -0.0035045 \\
\hline Gov & & $0.0134846^{*}$ & & $0.0138176^{*}$ \\
\hline Total Asset & $-3.13 \mathrm{E}-11^{* * *}$ & $-3.33 \mathrm{E}-11^{* * *}$ & $-3.22 \mathrm{E}-11^{* * *}$ & $-3.39 \mathrm{E}-11^{* * *}$ \\
\hline Market Cap & 3. $14 \mathrm{E}-11^{* * *}$ & 3. $27 \mathrm{E}-11^{* * *}$ & $3.50 \mathrm{E}-11^{* * *}$ & $3.54 \mathrm{E}-11^{* * *}$ \\
\hline Country & 0.044816 & $0.0743996^{*}$ & $0.0824362^{* *}$ & $0.1130349^{* * *}$ \\
\hline Constant & $0.8213441^{* * *}$ & 0.2697087 & $0.844264^{* * *}$ & 0.3290152 \\
\hline Observations & 362 & 362 & 363 & 363 \\
\hline R-squared & 0.1727 & 0.144 & 0.2381 & 0.1995 \\
\hline \multicolumn{5}{|l|}{ Number of } \\
\hline Company & 77 & 77 & \multicolumn{2}{|l|}{77} \\
\hline Prob>chi2 & 0.0000 & 0.0000 & 0.0000 & 0.0000 \\
\hline \multirow{2}{*}{$\begin{array}{c}\text { Statistical } \\
\text { Significance } \\
\text { Level }\end{array}$} & Random & Random & Random & Random \\
\hline & ${ }^{*} p<0.1$ & ${ }^{* *} p<0.05$ & ${ }^{* * *} p<0.01$ & \\
\hline
\end{tabular}

TABLE 11.

REGRESSION RESULT MODEL 5-8

\begin{tabular}{|c|c|c|c|c|}
\hline Models & 5 & 6 & 7 & 8 \\
\hline \multirow[t]{2}{*}{ Variable } & Stock Price & Stock Price & $P / E$ & $P / E$ \\
\hline & Coefficient & Coefficient & Coefficient & Coefficient \\
\hline ESG & $0.0182185^{*}$ & & -0.0108014 & \\
\hline Env & & $0.0236367^{* * *}$ & & -0.0014739 \\
\hline Soc & & -0.0044102 & & $-0.0081635^{*}$ \\
\hline Gov & & -0.0234034 & & $-0.0142435 *$ \\
\hline Total Asset & $-8.75 \mathrm{E}-11^{*}$ & $-7.37 \mathrm{E}-11^{*}$ & $-2.23 \mathrm{E}-11^{* *}$ & $-3.12 \mathrm{E}-12$ \\
\hline Market Cap & $1.29 \mathrm{E}-10^{* * *}$ & $1.14 \mathrm{E}-10^{* * *}$ & 4.47E- $11^{\text {** }}$ & $2.25 \mathrm{E}-11^{* *}$ \\
\hline Country & -1.44397 & -1.918713 & $0.7534185^{* * *}$ & $0.1734825^{* * *}$ \\
\hline Constant & 6.623518 & 9.403315 & $1.233127^{* *}$ & $4.621167^{* * *}$ \\
\hline Observations & 382 & 382 & 380 & 380 \\
\hline $\begin{array}{l}\text { R-squared } \\
\text { Number of }\end{array}$ & 0.2768 & 0.3344 & 0.2421 & 0.3709 \\
\hline Company & 77 & 77 & 77 & 77 \\
\hline Prob>chi2 & 0.0000 & 0.0000 & 0.0000 & 0.0000 \\
\hline \multirow[t]{2}{*}{$\begin{array}{l}\text { Statistical } \\
\text { Significance } \\
\text { Level }\end{array}$} & Fixed & Fixed & Fixed & Random \\
\hline & ${ }^{*} \mathrm{p}<0.1$ & ${ }^{* *} p<0.05$ & $* * *<<0.01$ & \\
\hline
\end{tabular}

Based on the regression result in the Table 10, we can see that the ESG variable is highly significant and positive correlation with ROA and ROC. While on the other hand, there is no significant influence from individual ESG factors (Environmental, Social, and Governance) towards the firm's ROA. Moreover, the Environmental factor has positive significant correlation with the firm's ROC. The 
$\mathrm{R}$-square for the model one until four are $0.1727,0.144$, 0.2381 and 0.1995 respectively.

Moving on to Table 11, there is no significant correlation between the ESG as a whole and Stock Price. However, the Environmental aspect is significant and positively correlated to the firm's Stock Price. While on the other hand, there is no sign of a significant correlation between the ESG and the firm's P/E. The R-square for the model five until eight are $0.2768,0.3344,0.2421$ and 0.3709 respectively.

\section{CONCLUSION}

This study tries to find the correlation between Environmental, Social, and Governance (ESG) disclosures on firm financial performance as measured by its accounting and market based. The financial indicators are measured by considering the data from listed real estate companies from year 2014 until 2018 within the G7 (Italy, Japan, United Kingdom, Canada, France, Germany, and the United States) context as group of developed countries. The countries in G7 was chosen as subject of the study due the high concerns of specific stakeholders, for example, regulators, shareholders, creditors, investors, environmentalists, and the media in disclosing CSR information in the developed nations.

G7 also declared that they emphasized, in particular, the UN Global Compact as an important CSR initiative. On the summit declaration, they mentioned to strengthen the voluntary approach of CSR by encouraging the improvement of the transparency of private companies' performances with respect to CSR. Moreover [32], stated that the most notable and robust drivers of global CSR reporting regulation are the GDP level of a country and the promotion efforts from international organizations targeted to that country. The author also stated that one of the factors which stimulates the growth of CSR regulation is the increasing expectation from stakeholders and the civil society on governments to regulation firms' behavior.

The author chooses this particular topic because there is a growing interest in ESG criteria while at the same time, these ratings have not been around for very long, so the data are sparse. Moreover, the growing market size of Socially Responsible Investing (SRI) along with the importance of ESG disclosure that has been recognized by more and more regulatory agencies, exchanges, and investors pique our interest in conducting a study in this particular field. The environmental actions of the company is related to their efforts in building a good impact for the environment by following the regulations related to that particular aspect. The social actions is more about how they well they threat the stakeholders as well as the communities in which the firm is operating, The governance aspect is incorporating the firm's integrity and ethical behavior within the management system of the company including the board of directors.
The results from the observations collected from the seven markets have revealed that there is a significant influence of the ESG disclosure as a whole on the real estate companies financial performance as measured by accounting indicators such as ROA and ROC. However, the market based measure such as Stock Price and P/E do not have any correlation with the ESG factor as a whole.

This highlights the difference in the firms performance based on returns or market value. ROA and ROC measure the overall effectiveness of management in generating returns, whereas Stock Price and P/E measure the financial markets performance. This is aligned with the previous study done by [53] who stated that a strong ESG commitment would imply more information about the expected cash flow distribution, decrease principal-agent costs, as well as lower the investors' risk premiums. Moreover, cost of capital might be decreased due to the readiness of the socially responsible investors in accepting a lower return from a socially responsible company. The study also suggests that the firms with higher ESG commitments are better in terms of their operations and financial.

The study results also indicate that there is a statistically significant positive relationship between Environmental disclosure and firm ROC as well as Stock Price. Meaning that more common stock investors take firm's Environmental concerns into consideration. This finding is aligned with the previous research by [54] for investors, paying attention to environment-related risks is particularly important in the age of social media. Today's consumers can easily spread news and communicate much faster in a sense that they could shame a company for its unsustainable practices. Because of this heightened awareness, [54] predicts that new environmental regulations would follow public protest faster than in the past. Thus, the aims of building a positive image of the companies made Corporate Social Responsibility became one of the ways in increasing the value of the companies.

This study results also revealed that there's no significant influence of the Social and Governance factor on firm financial performance. Since prior studies usually examine the relationship between firm financial performance and CSR/ESG as a whole and not specific aspects of ESG. Therefore, our study contributes new knowledge to the extant literature on ESG as well as firm financial performance of real estate companies.

\section{Recommendations}

The main recommendation is that the corporations, investors, regulator and stakeholders need to consider ESG disclosure. For regulators, there must be improvements related to reports guidelines to disclose CSR activities that will eventually help to facilitate the users with a clearer and more reliable CSR information. Some evidence-based research proved that in the developing nations, the ESG disclosure practices are scarce, that's the reason why it is 
advisable to start creating a more integrated reporting that would help to cover variety reports within a presentation [55].

This may be due to the voluntary practices across nations. Therefore, it is advisable for the developing nations to start to consider disclosing such information as it will eventually give advantages for the firm performance. This could be done by having the Financial Reporting Council (FRC) cooperate with academics, professional regulators and other regulatory authorities within the countries towards developing an acceptable integrated reporting framework that will increase transparency and accountability in the reporting.

For the investors, they could try to develop some investment strategies that take into account the changes in the ESG disclosure score since it would predict possible changes in the firm's future stability and performance. For the common stock holders, they still have to consider the effect of the fluctuations on the market value in stock market. As an addition, the weakness of using marketbased financial performance is the fact that these measures represent the investors' expectations of the firm's general performance rather than measures the actual company's performance.

\section{FURTHER RESEARCH}

This study has revealed some correlations between the different performance indicators which then could be used as a further research in order to create an analysis of the companies' future performance and their current performance so that the study will be expanded. Moreover, future research could also try to investigate whether the ESG score could be assumed as the companies' level of ESG effort or not. Because it could be that companies with a high ESG disclosure has better ESG efforts or there might be an effect from such a high regulated company towards the companies' ESG disclosure level, thus explain the high ESG disclosure.

\section{ACKNOWLEDGMENT}

This research was supported/partially supported by School of Business and Management, Institut Teknologi Bandung. The author realizes that this final project may contain some mistakes in contents and technical writing due to the limited capability of the author. Hence, the author welcomes any feedbacks and suggestions from the readers in order to improve the quality of this research. Lastly, the author hopes that this research could be useful for the readers and for the purpose of future research.

\section{REFERENCES}

R. Gray, R. Kouhy, and S. Lavers, "Corporate social and environmental reporting A review of the literature and a longitudinal study of UK disclosure," Accounting, Audit. Account. J., vol. 8, no. 2, pp. 47-77, May 1995. investment disclosure practices of the world's largest pension funds," Account. Res. J., vol. 23, no. 3, pp. 302-318, 2010.

[3] L. Coleman, K. Maheswaran, and S. Pinder, "Narratives in managers' corporate finance decisions," Account. Financ., vol. 50, no. 3, pp. 605-633, Sep. 2010.

[4] Global Sustainable Investment Alliance, 2014 Global Sustainable Investment Review. 2014.

[5] N. Cucari, S. Esposito De Falco, and B. Orlando, "Diversity of Board of Directors and Environmental Social Governance: Evidence from Italian Listed Companies," Corp. Soc. Responsib. Environ. Manag., vol. 25, no. 3, pp. 250-266, May 2018.

[6] B. Fung, "The demand and need for transparency and disclosure in corporate governance," Univers. J. Manag., vol. 2, no. 2, pp. 72-80, 2014.

[7] K. Kokubu and T. Kurasaka, "Corporate Environmental Accounting: A Japanese Perspective," in Environmental Management Accounting: Informational and Institutional Developments, Dordrecht: Springer, 2002, pp. 161-173.

[8] Y. Xiao, R. Faff, P. Gharghori, and D. Lee, “An empirical study of the world price of sustainability," J. Bus. Ethics, vol. 114, no. 2, pp. 297-310, May 2013.

[9] U. Sekaran and R. Bougie, Research Methods for Business : A Skill-Building Approach. New York: Wiley, 2009.

[10] W. Ali, J. G. Frynas, and Z. Mahmood, "Determinants of Corporate Social Responsibility (CSR) disclosure in developed and developing countries: A literature review," Corporate Social Responsibility and Environmental Management, vol. 24, no. 4. John Wiley and Sons Ltd, pp. 273-294, 01-Jul-2017.

[11] D. Jamali and C. Karam, "Corporate social responsibility in developing countries as an emerging field of study," Int. J. Manag. Rev., vol. 20, no. 1, pp. 32-61, Jan. 2018.

[12] P. Perry and A. Ahmad, "Islamic and Buddhist Perspectives of Corporate Social Responsibility, in A Ortenblad," in Research Handbook on Corporate Social Responsibility in Context, A. Örtenblad, Ed. Cheltenham, UK: Edward Elgar Publishing, Inc., 2016, pp. 69-87.

[13] PwC, The Future of Corporate Reporting. PwC, 2015.

[14] J. R. Evans and D. Peiris, "The relationship between environmental social governance factors and stock returns," SSRN Electron. J., Jan. 2012.

[15] T. Donaldson, L. E. Preston, and L. E. E. E. Preston, "Theory the stakeholder of the concepts, evidence, corporation: And implications," Management, vol. 20, no. 1, pp. 65-91, 1995.

[16] I. E. Ahmed, "The impact of corporate governance on islamic banking performance: The case of UAE islamic banks," J. Bank. Financ., vol. 2017, no. 9, pp. 1-10, 2017.

[17] M. Ammann, D. Oesch, and M. M. Schmid, "Corporate governance and firm value: International evidence," J. Empir. Financ., vol. 18, no. 1, pp. 36-55, 2011.

[18] C. T. Horngren and G. L. Sundem, Introduction to Management Accounting. Englewood Cliffs, New Jerseyu: Prentice-Hall, 1990.

[19] S. Buniamin, N. Nazli, and N. Ahmad, "An integrative perspective of environmental, social and governance (ESG) reporting: A conceptual paper," in Proceedings of the International Conference on Accounting Studies (ICAS) 2015, 2015, pp. 9-16.

[20] K. T. K. Wong, "A literature review on environmental, social and governance reporting and it's impact on financial performance," Austin J. Bus. Adm. Manag., vol. 1, no. 4, pp. 14, 2017.

[21] A. Konigs and S. Dirk, "Herausforgerung und rechtliche Qualifikation fur die Finanzkommunikation deutscher Grobunternehmen," Finanzbetrieb. pp. 649-652, 2007. A. Bassen, "Carbon Disclosure Project Report 2007," Frankfurt. P. M. Clarkson, Y. Li, G. D. Richardson, and F. P. Vasvari, "Revisiting the relation between environmental performance and environmental disclosure: An empirical analysis," Accounting, Organ. Soc., vol. 33, no. 4-5, pp. 303-327, May 
2008.

[24] G. Dorfleitner, S. Utz, and M. Wimmer, "Where and when does it pay to be good? A global long-term analysis of ESG investing," SSRN Electron. J., 2013.

[25] A. Kocmanova, M. Docekalova, P. Nemecek, and I. Simberova, "Sustainability: Environmental, social and corporate governance performance in Czech SMEs," in WMSCI 2011 - The 15th World Multi-Conference on Systemics, Cybernetics and Informatics, Proceedings, 2011.

[26] A. B. Carroll, "Corporate social responsibility: Evolution of a definitional construct," Bus. Soc., vol. 38, no. 3, pp. 268-295, Sep. 1999.

[27] K. Keasey, S. Thompson, and M. Wright, Corporate Governance : Economic and Financial Issues. Norfolk: Oxford University Press, 1997.

[28] S. Deakin, "The corporation as commons: rethinking property rights, governance and sustainability in the business enterprise," Queens. Law J., vol. 37, no. 2, pp. 339-381, 2012.

[29] T. Cadman, "Re-Casting the Frame of Corporate Social Responsibility and Responsible Investment: An Environmental and Social Perspective," SSRN Electron. J., Jul. 2012.

[30] D. Koehler and E. Hespenheide, "Finding the Value in Environmental, Social and Governance Performance by Dinah Koehler, Eric Hespenheide:: SSRN," Deloitte Rev., vol. 12, 2013.

[31] A. Kocmanova, P. Nemecek, and M. Docekalova, "Environmental, Social and Governance (ESG) key performance indicators for sustainable reporting," in The 7th International Scientific Conference "Business and Management $2012, " 2012$.

[32] H. Wen, "Global Corporate Social Responsibility Reporting Regulation: Drivers and Impacts on Sustainable Development." 2017.

[33] Edelman, "2009 Edelman Trust Barometer," 2009.

[34] Sustainable Stock Exchanges, "TMX Group Inc. (Toronto Stock Exchange)," Sustainable Stock Exchanges. [Online]. Available: https://sseinitiative.org/fact-sheet/tmx/.

[35] R. G. Eccles, I. Ioannou, and G. Serafeim, "The impact of corporate sustainability on organizational processes and performance," Manage. Sci., vol. 60, no. 11, pp. 2835-2857, Nov. 2014.

[36] C. Marquis and C. Qian, "Corporate social responsibility reporting in China: Symbol or substance?," Organ. Sci., vol. 25, no. 1, pp. 127-148, Jan. 2014.

[37] A. S. Yudharma, Y. W. Nugrahanti, and A. B. Kristano, "Pengaruh biaya corporate social responsibility terhadap kinerja keuangan dan nilai perusahaan," DeReMa (Development Res. Manag. J. Manaj., vol. 11, no. 2, pp. 171-190, Sep. 2016.
[38] F. Küçükbay and T. A. Fazlılar, "The Relationship between Firms' Environmental Performance and Financial Performance: The Case of Turkey," Kaposvár, Hungary, 2016.

[39] A. Michel and I. Shaked, "Does business diversification affect performance?," Financ. Manag., vol. 13, no. 4, p. 18, 1984.

[40] S. Vance, "Are socially responsible corporations good investment risks?," Manag. Rev., vol. 64, pp. 18-24, 1975.

[41] D. Lamond, "Corporate social responsibility: Making trade work for the poor," Manag. Decis., vol. 45, no. 8, Sep. 2007.

[42] M. E. Porter and C. van der Linde, "Toward a New Conception of the Environment-Competitiveness Relationship," J. Econ. Perspect., vol. 9, no. 4, pp. 97-118, 1995.

[43] C. Blanco et al., "A pilot study of impulsivity and compulsivity in pathological gambling," Psychiatry Res., vol. 167, no. 1-2, pp. 161-168, May 2009.

[44] M. Orlitzky, F. L. Schmidt, and S. L. Rynes, "Corporate Social and Financial Performance: A Meta-analysis," Organ. Stud., vol. 24, no. 3, pp. 403-441, 2003.

[45] K. Yilmaz, "Comparison of quantitative and qualitative research traditions: Epistemological, theoretical, and methodological differences," Eur. J. Educ., vol. 48, no. 2, pp. 311-325, Jun. 2013.

[46] M. De Klerk, C. de Villiers, and C. van Staden, "The influence of corporate social responsibility disclosure on share prices: Evidence from the United Kingdom," Pacific Account. Rev., vol. 27, no. 2, pp. 208-228, Apr. 2015.

[47] D. N. Gujarati, Basic Econometrics, 4th ed. New York: Mc Graw Hill, 2004.

[48] D. Gujarati and D. Porter, Dasar-Dasar Ekonometrika Edisi 5 Buku 2. Jakarta: Salemba Empat, 2012.

[49] J. T. McClave, P. G. Benson, and T. Sincich, Statistics for Business and Economics. Upper Saddle River, New Jersey: Pearson Prentice Hall, 2008.

[50] B. Baltagi, Econometric Analysis of Panel Data. England: John Wiley \& Sons, Ltd, 2005.

[51] C. Brooks, Introductory Econometrics for Finance. Cambridge: Cambridge University Press, 2008.

[52] J. F. Hair, R. E. Anderson, and R. L. Tatham, Multivariate Data Analysis with Readings. Englewood Cliffs, New Jersey: Prentice Hall International Inc, 1995.

[53] M. Cajias, F. Fuerst, and S. Bienert, "Can investing in corporate social responsibility lower a company's cost of capital?," Stud. Econ. Financ., vol. 31, no. 2, pp. 202-222, 2014.

[54] R. Jagannathan, J. Liberti, B. Liu, and I. Meier, “A firm's cost of capital," Аnnu. Rev. Financ. Econ., vol. 9, no. 1, pp. 259282, Nov. 2017.

[55] Integrated Reporting, "Discussion Paper on Towards Integrated Reporting - Communicating Value in the 21 st Century," 2011. 